4-1-2008

\title{
Stressors and Supports for Baccalaureate Nursing Students Completing An Accelerated Program
}

\author{
Marilyn L. Weitzel \\ Cleveland State University, m.weitzel@csuohio.edu \\ Cheryl P. McCahon \\ Cleveland State University
}

Follow this and additional works at: https://engagedscholarship.csuohio.edu/nurs_facpub

Part of the Nursing Commons

How does access to this work benefit you? Let us know!

Publisher's Statement

NOTICE: this is the author's version of a work that was accepted for publication in Journal of Professional Nursing. Changes resulting from the publishing process, such as peer review, editing, corrections, structural formatting, and other quality control mechanisms may not be reflected in this document. Changes may have been made to this work since it was submitted for publication. A definitive version was subsequently published in Journal of Professional Nursing, 24, 2, April 2008] DOI\#10.1016/j.profnurs.2007.06.017

\footnotetext{
Recommended Citation

Weitzel, Marilyn L. and McCahon, Cheryl P., "Stressors and Supports for Baccalaureate Nursing Students Completing An Accelerated Program" (2008). Nursing Faculty Publications. 43.

https://engagedscholarship.csuohio.edu/nurs_facpub/43
}

This Article is brought to you for free and open access by the School of Nursing at EngagedScholarship@CSU. It has been accepted for inclusion in Nursing Faculty Publications by an authorized administrator of EngagedScholarship@CSU. For more information, please contact library.es@csuohio.edu. 


\title{
Stressors AND SUPPORTS for Baccalaureate Nursing Students Completing an Accelerated Program
}

\author{
MARILYN L. WEITZEL, PHD, RN, AND CHERYL P. MCCAHON, PHD, RN
}

$T^{1}$ HE IMMEDIACY OF the current nursing shortage has demanded educational responses to build and sustain a nursing workforce sufficient to meet the health care needs of society. Schools of nursing across the country have been challenged to take more students, streamline curricula, and graduate more nurses as quickly as possible. In response to these challenges, in recent years, there has been increased interest in accelerated second-degree programs in nursing (Davidson, 2002). The American Association of Colleges of Nursing (2006) Web site indicates that there are 168 accelerated second-degree baccalaureate programs now in operation, and this number represents a dramatic increase over the past 5 years.

Accelerated nursing programs are attractive in that they admit individuals who already hold a bachelor's degree in a nonnursing field and streamline or accelerate nursing course content in such a way as to graduate individuals with a bachelor of science in nursing in 18 months or less. Graduates of accelerated programs have a sustained track record of passing the National Council Licensure Examination and entering the workforce as registered nurses. Little is known about these students' experiences in nursing school, and the literature does not address issues such as the students' perceptions of day-to-day activities. As more faculty are teaching accelerated students, information about students' attitudes and perceptions could help faculty assist these students as they matriculate through a demanding educational program.

Faculty at the Cleveland State University (CSU) began teaching in a newly established accelerated program in 2001 and found that the accelerated students' approach is different from that of traditional undergraduate nursing students. CSU faculty described these students as intense, competitive, and eager learners who were well prepared for class and clinical experience and who exhibited stress related to their return to school as mid-career adults as well as the life adjustments required to sustain a full academic load 
over four consecutive semesters. We engaged in an investigation of these students' experiences to learn about the students' attitudes and perceptions of their educational experience. This article presents the results of the study a preliminary descriptive evaluation of three groups of accelerated nursing students as they completed their final semester of a bachelor of science in nursing program.

\section{Review of the Literature}

Although accelerated nursing programs have been offered for more than 20 years, there is little empirical evidence about the students' outcomes or their experiences with these programs. The literature presents descriptions of these programs (Bennett, Bremner, \& Sowell, 2003; Rideout, 1995; Roberts, Mason, \& Wood, 2001; Shiber, 2003) and reports that such programs are successful and effective. Professional opinions about these programs have also been reported (Duke, 2001; Renaud \& Miller, 2003) and concluded that accelerated programs produce competent beginning practitioners in nursing.

The characteristics of accelerated nursing students have been reported by Congelosi and White (2005). Demographically, these students are older, have more racial diversity as well as a higher representation of men (twice as many), and are more likely to be married as compared with their traditional counterparts. Most often, their first baccalaureate degrees are in biology or psychology. Accelerated students are more likely than their traditional counterparts to cite having a career goal to practice as a clinical care nurse.

Academically, these students are described as motivated, engaged in learning, and intolerant of busy work and "fluff courses" (Duke, 2001). Compared with traditional nursing students, accelerated students score higher on the National Council Licensure Examination when their pass rates are compared with others (Seldomridge \& DiBartolo, 2005), get better grades in nursing classes (Seldomridge \& DiBartolo, 2005), get better grades on Web-based courses (Kearns, Shoaf, \& Summey, 2004), and demonstrate less ability in practicebased critical thinking activities (Brown, Alverson, \& Pepa, 2001; Kearns et al., 2004).

There is no literature on accelerated nursing students' perceptions or experiences, the activities that support or inhibit their work, and their recommendations to faculty regarding needs, challenges, supports, or teaching/ learning strategies. Many faculty assume that literature on adult learners would apply to this group of students. According to Knowles (1980), adult learners are independent learners, need to apply their new learning, and see the immediate relevance of the content; however, there is no documentation from the students' view that these strategies are viewed as helpful. Although Seldomridge and DiBartolo (2005) reported a higher stress level for accelerated baccalaureate nursing students, there is no evidence reported as to what teaching/ learning strategies are stressful or supportive from the perspective of the students.

\section{Study Purpose/Study Questions}

The purpose of this study was to describe the students' attitudes and perceptions regarding factors that served as stressors and supports during their course of study. Specifically, the study had two research questions:

I. What factors did students believe contributed to their stress?

2. What factors contributed to students' supports or ability to deal with stress?

\section{Study Framework}

Stress theory served as a framework for this study. Based on the work of Antonovsky (1981), a specific event may be considered as a stressor by one individual but not by another. Thus, the meaning one gives to an event determines its impact on the individual, which could vary from noxious stimuli calling for an adaptive

Table I. Factors Explored Regarding the Accelerated Nursing Program




response to simply a routine matter. Individuals have resources that they use to cope with stressors in their lives, and the number and kind of resources available to each individual ultimately dictate whether that individual experiences a stress state or an adaptive state.

From within this framework, it becomes clear that faculty may not know which events are contributing to student learning, are causes for student stress, or are perceived as supports to learning or to living a lifestyle conducive to academic success. The faculty must ask the students to report from their own experiences. Because the CSU nursing program uses a conceptual framework based on the stress theory with resources for coping, it seemed appropriate to frame the study in this framework.

\section{Methodology}

\section{Protocol}

Students completing an accelerated nursing program were asked to complete an anonymous written survey designed to elicit factors the students felt contributed to their stress and to their perceived supports. In addition, students were interviewed by a trained research assistant with open-ended questions, permitting the students to speak freely about their reflections.

\section{Sample}

The study sample was a convenience sample of 69 students who were completing the last week of a foursemester accelerated baccalaureate program in the Midwest. We wanted to collect information at the end of the program to allow for a more complete view of stressors and supports that would be reflective of the entire program. All graduates of three cohorts were asked to participate in the study, and all did. Twelve of these students were male and 57 were female, with their ages ranging from 22 to 60 years.

\section{Research Tool}

We found no established tool that would evaluate student stressors and supports in an accelerated nursing program setting. Thus, a tool was developed based on literature

Table 2. Stressors and Supports Identified $(n=60)$

Students stating the item

as a stressor/support (\%)

\begin{tabular}{ll}
\hline Major stressors & 74 \\
Fast pace & 62 \\
Group assignments & 93 \\
Not enough clinical experience & 74 \\
Too many reading assignments & 65 \\
Too many projects & \\
Supports & 93 \\
Lecture was helpful & 81 \\
Nursing advisers & 80 \\
Their peers & 75 \\
Faculty fairness & 69 \\
Their families & \\
\hline
\end{tabular}

Table 3. Summary of Interview Data $(n=5 \mathrm{I})$

Number of reports

\begin{tabular}{ll}
\hline Identified stressors & \\
Paperwork too heavy & 30 \\
Not enough clinical experience & 25 \\
Workload too heavy & 30 \\
Group assignments & 27 \\
Identified supports & \\
NRL & 25 \\
Clinical experience & 40 \\
Faculty & 30 \\
\hline
\end{tabular}

cited previously, comments that previous accelerated students made during exit interviews, and anecdotal information provided by nursing faculty. We evaluated data that we had about accelerated student experiences and listed those factors consistently mentioned as academic or personal stressors or supports. The result was 34 items reflecting various aspects of the educational experience. These 34 items were placed into a survey in which students were asked to reflect their perceptions about each on a 5-point Likert scale and to indicate whether each aspect was perceived as a stressor or a support. The 34 items are presented in Table 1.

Test retest reliability evaluated with data from the study sample indicated a Cronbach's alpha of 0.77 . The tool was assumed to have face validity. Furthermore, when the interview data were compared with the survey data, we looked for consistency of stressors/supports between the two data gathering methods as a means of validation of the tool.

\section{Procedure}

Once institutional review board approval was obtained, one of us approached students in class, informed them about the study, and asked them to volunteer. Those who agreed to participate signed an informed consent form and were given the survey to complete. Once they returned the survey, the participants were asked to make an appointment with the research assistant. The assistant was a staff person at the university, unknown to the students, whom we trained to use a semistructured list of questions to ask participants to comment on stressors, resources, and the experience of being a student in the program. The assistant recorded student comments manually, without individual student identifiers.

\section{Findings}

Results of the survey were evaluated by collapsing the Likert scale such that the first and second ratings were interpreted as stressors, the middle rating was interpreted as neutral, and the fourth and fifth ratings were interpreted as supports. Of the 34 items, the aspects that more than half of the students interpreted as stressors were as follows: too many writing assignments; too many reading assignments; heavy workload; family responsibilities; the fast pace of the program; no vacation break in the program; and group assignments. The aspects that more than half of 
the students interpreted as supports were as follows: individual faculty; peers; nursing school advisers; class lectures; and their families. Table 2 lists the major stressors and supports identified and the number of students who cited each as a stressor/support.

The interview data paralleled the survey data. Students reiterated that the workload was too heavy: there were too many writing assignments and not enough time in the clinical unit. Furthermore, they reported being supported by the Nursing Resource Laboratory (NRL), clinical experiences, and the faculty. (See Table 3.)

\section{Discussion}

It is perhaps not surprising that students report their main stressor to be the heavy workload of an accelerated program, in addition to family responsibilities. Faculty will undoubtedly agree that a heavy workload is part and parcel of an accelerated educational experience and that family issues and those situations outside the educational experience are not matters faculty can directly change. However, reviewing these data, faculty should reflect on aspects of the program that could be altered. When $88 \%$ of the students report that there are too many writing assignments, faculty must evaluate each assignment carefully to be absolutely certain that there is a clear learning objective for every assignment given and that this learning objective cannot be met in some alternate form. Likewise, reading assignments must be given in direct relation to objectives and planned use of the material gained from the reading. Prior to the study, CSU faculty had commented that accelerated students read assigned materials before class in contrast to their traditional counterparts, who often do not read the assigned materials. Given the difference between the two student groups, it is possible that faculty have assignments on lists with an assumption that assigned readings are optional for students. It would be unfair to provide lists to accelerated students and assume that those are not read. Thus, faculty must review reading lists and ensure that readings are needed and worth the relative time it takes to complete the readings. Research had documented the academic successes of accelerated students (Kearns et al., 2004; Seldomridge \& DiBartolo, 2005) and their characteristics of being motivated and engaged students (Renaud $\&$ Miller, 2003). It is essential to provide them with a workload that takes into account their overall schedule. One suggestion is that faculty across the curriculum map out the number of readings, tests, clinical papers, and classroom assignments and review as a group what they collectively are asking of this accelerated nursing group. Where assignments can be streamlined or dropped, that can be done. Faculty may look at the work in relation to the "need-to-know" versus "nice-toknow" criteria used often in designing texts.

The issue of group assignments is another interesting item and one over which faculty have control. Students disliked the group activities in part because of concerns about the grading. Students are concerned that the ones in the group who do not carry their load often receive the same grade as those who do the work. Accelerated students are often very competitive, and they do not want a weak student bringing their grades down.

Supports to the program included the NRL. In this space, students were taught procedures and were nurtured. Students returned to the NRL to practice specific skills when engaged in more advanced courses. Students rated their clinical experiences with patients very highly. Some commented that they were pleasantly surprised that patients accepted them as students so graciously. Students also commented on the professionalism and kindness of the faculty. The helpfulness of the faculty was rated highly as a support.

Lastly, there was consistency between survey and interview responses. The survey asked students to evaluate items as stressors or supports, and those were supported by the responses to open-ended questions in the interview, thus validating the research tool.

\section{Conclusions}

Previous literature reported that accelerated nursing students experience significant stress (Seldomridge \& DiBartolo, 2005), and the current study supports this observation. Although faculty cannot control or alleviate many aspects of that stress, there are some factors over which faculty have control: number of writing and reading assignments; number of group projects; and clinical assignments. Faculty also need to continue to be supportive, professional, and caring toward these students, who have many things to deal with in a fast-paced professional program.

The current data show that students view faculty to be a source of support equal to their peers and family. Faculty should understand that a faculty student relationship is of great importance to this group and use that relationship to continue supporting these students. Faculty availability and fairness are highly valued by students. Faculty may want to attend to being consistent in keeping office hours and being available before and after class. Students value the faculty being fair in giving each student time to learn and being awarded an equivalent grade for equivalent work. Fairness is correlated highly with a positive attitude toward the faculty. Furthermore, the role of school of nursing advisers as a source of support indicates that the practice of assigning professional academic advisers to this group of students is an important and valued student service, the impact of which may be overlooked by university and school administration.

We recommend further research on the perceptions of accelerated students in larger sample groups and in other types of nursing programs. This study was limited to one nursing program in the Midwest. We further suggest that research be conducted to assess the differences in perceptions between the faculty and the students regarding expectations. Faculty make assignments believing that it is necessary to have a certain 
amount of reading or writing of papers, whereas students perceive them as busy work and not useful.

\section{Acknowledgments}

We thank the Nu Delta Chapter of Sigma Theta Tau at the CSU for funding this study. We also thank Noreen Frisch PhD, RN, for her support and coaching in the writing of this article.

\section{References}

American Association of Colleges of Nursing. (2006). http:// www.aacn.nche.edu/

Antonovsky, A. (1981). Health, stress and coping. San Francisco: Jossey Bass.

Bennet, D., Bremner, M., \& Sowell, R. (2003). A partnership model to address the nursing shortage. Nursing Leadership Forum, 8, 4752.

Brown, J. H., Alverson, E., \& Pepa, C. (2001). The influence of a baccalaureate program on traditional, RN BSN, and accelerated students' critical thinking abilities. Holistic Nursing Practice, 48.

Congelosi, P., \& White, K. (2005). Accelerated nursing programs: What do we know? Nursing Education Perspectives, 113146.
Davidson, M. (2002). A look at second degree nursing programs. Nursing Spectrum, 2325.

Duke, M. (2001). On the fast track: Speeding nurses into the future: A two year bachelor of nursing for graduates of other disciplines. Collegian, 1418.

Kearns, L., Shoaf, J., \& Summey, M. (2004). Performance and satisfaction of second degree BSN students in Web based and traditional course delivery environments. Journal of Nursing Education, 280284.

Knowles, M. (1980). The modern practice of adult education: From pedagogy to andragogy. New York: Cambridge.

Renaud, M., \& Miller, J. (2003). The accelerated baccalaure ate option for nursing education. Nursing Leadership Forum, 2, 139142.

Rideout, K. (1995). A case study of nontraditional nursing students enrolled in a baccalaureate degree nursing program. Unpublished master's thesis, The University of Rochester, Rochester, New York.

Roberts, K., Mason, J., \& Wood, P.A. (2001). Comparison of a traditional and an accelerated basic nursing education program. Contemporary Nurse.

Seldomridge, L., \& DiBartolo, M. (2005). A profile of accelerated second bachelor's degree nursing students. Nurse, 6568.

Shiber, S. (2003). A nursing education model for second degree students. Nursing Education Perspectives, 24, 135138. 